\title{
Colonic short chain fatty acids mediate jejunal growth by increasing gastrin
}

\author{
K J Reilly, W L Frankel, A M Bain, J L Rombeau
}

\begin{abstract}
Colonic infusion of short chain fatty acids (SCFAs) is trophic to rat jejunum and is associated with raised jejunal gastrin concentration. This study examined the hypothesis that the jejunal trophic effects of colonic SCFAs are mediated in part by gastrin. Forty six adult rats underwent caecectomy to reduce endogenous production of SCFA, ileocolonic anastomosis, and placement of a colonic infusion catheter. SCFA (70 $\mathrm{mM}$ acetate, $35 \mathrm{mM}$ propionate, $20 \mathrm{mM}$ butyrate) or saline were continuously infused into the colon for seven days. Rats received either a gastrin receptor blocker $(L-365,260)$ or a control solution and animals were killed on day 8. SCFA infused into the colon acted systemically to significantly improve jejunal structure and increase jejunal gastrin concentrations. Gastrin receptor blockade abolished effects of SCFA on jejunal DNA, protein, crypt cell proliferation, and gastrin. Gastrin blockade did not reduce SCFA induced augmentation of villous height or crypt depth. It is concluded that the jejunal trophic effects of colonically infused SCFA are mediated in part by gastrin.

(Gut 1995; 37: 81-86)
\end{abstract}

Keywords: short chain fatty acids, gastrin, enteroglucagon.

Short chain fatty acids (SCFAs) are the one to six carbon volatile fatty acids, predominantly acetate, propionate, and butyrate. They are produced in the colon by microbial fermentation of dietary polysaccharides and are the major luminal organic anions in the human and rat colon. ${ }^{1-3}$ Importantly, butyrate is the preferred oxidative fuel of the colonocyte. ${ }^{4-6}$

SCFAs are trophic to rat colon and jejunum when given by colonic infusion. ${ }^{7-12}$ The trophic effects of SCFAs on the colon require direct, mucosal contact, while SCFAs act on the jejunum by a systemic mechanism involving the autonomic nervous system. ${ }^{10-12}$ Previous investigation from our laboratory has shown that both the parasympathetic and sympathetic divisions of the autonomic nervous system must be intact for colonic SCFA mediated jejunal trophism to occur. ${ }^{11} 12$ Additionally, colonic SCFA infusion is associated with increased jejunal gastrin concentrations, which may be important in mediating jejunal trophism. ${ }^{10}$ The purpose of this experiment was to discover if gastrin mediates the trophic effects of colonically infused SCFA on rat jejunum.

\section{Methods}

EXPERIMENT 1

Male Sprague-Dawley rats weighing 200 to 250 grams (Charles Rivers Laboratories, Portage, MI) were housed in individual cages and fed rat chow and water ad libitum to acclimatise at least five days before the start of the experiment. This study was approved by the Institutional Animal Care and Use Committee at the University of Pennsylvania.

Rats were placed in individual cages with raised wire floors to limit intake of bedding material and maintained in a light, humidity, and temperature controlled environment. All animals were fed fibre free diets containing 5\% $\mathrm{w} / \mathrm{w}$ kaolin (Dyets, Bethlehem, PA) for five days before surgery. Water was provided ad libitum throughout the study.

On the day of surgery, rats were anaesthetised with pentobarbital $(50 \mathrm{mg} / \mathrm{kg}$ body weight intraperitoneally), the ileum and colon were transected $1 \mathrm{~cm}$ from the caecum, and the caecum was removed to reduce endogenous SCFA production. An end to side anastomosis was performed between the terminal ileum and the proximal ascending colon with interrupted 6-0 polypropylene suture. An infusion catheter (internal diameter 0.03 inches, Baxter, McGaw Park, IL) was placed into the proximal end of the colon and secured with a 5-0 purse string suture, tunnelled subcutaneously, exteriorised at the interscapular area, and connected to a spring and swivel device (Instech, Polymouth Meeting, PA) to permit concurrent infusion and ambulation within the cage.

Rats $(n=46)$ were randomly assigned to receive either a gastrin receptor blocker, L$365,260(5 \mathrm{mg} / \mathrm{kg} / \mathrm{d}$ in $0.9 \% \mathrm{NaCl}$; Merck, Cincinnati, $\mathrm{OH}$ ), or control (vehicle, $0.9 \%$ $\mathrm{NaCl}$ ) by twice daily gavage. $\mathrm{L}-365,260$ is a high affinity $\left(\mathrm{K}_{\mathrm{i}}=1 \cdot 1 \pm 0.4 \mathrm{nM}\right)$ non-peptide antagonist of gastrin/CCK-B receptors. ${ }^{13} 14$ After oral administration, L-365,260 has an onset of action of less than five minutes and a half life of 8-12 hours. ${ }^{13-20}$ Oral L-365,260 has been shown to consistently antagonise the action of gastrin on acid secretion in rats in a dose dependent fashion. ${ }^{14} 1920$ The first dose of gastrin receptor blocker or control was given two hours preoperatively and the last dose was given two hours before the rats were killed.

Postoperatively, animals were assigned to one of two colonic infusion groups: SCFA (70 $\mathrm{mM}$ acetate, $35 \mathrm{mM}$ propionate, $20 \mathrm{mM}$ butyrate, pH 6.1; Sigma, St Louis, MO) or saline (Sorenson's phosphate buffer, iso-osmolar with SCFA solution, $\mathrm{pH}$ 6.1). Infusions
Correspondence to: Department of Surgery, Pennsylvania, 3400 Spruce Street, Philadelphia, PA 19104, USA.

Accepted for publication 25 October 1994 
TABLE I Effect of SCFAs and gastrin receptor blocker (GRB) on jejunal weight and plasma gastrin

\begin{tabular}{lll}
\hline & $\begin{array}{l}\text { fejunal weight } \\
(\mathrm{mg} / \mathrm{cm})\end{array}$ & $\begin{array}{l}\text { Plasma gastrin } \\
(\mathrm{pg} / \mathrm{ml})\end{array}$ \\
\hline Saline/control & $67 \cdot 6(1 \cdot 5)$ & $65 \cdot 0(5 \cdot 6)$ \\
SCFA/control & $77 \cdot 0(3 \cdot 6)^{\star}$ & $52 \cdot 5(6 \cdot 2)$ \\
Saline/GRB & $78 \cdot 1(3 \cdot 0)$ & $67 \cdot 8(7 \cdot 8)$ \\
SCFA/GRB & $80 \cdot 0(2 \cdot 6)$ & $62 \cdot 2(5 \cdot 0)$ \\
\hline
\end{tabular}

Data are mean $(\mathrm{SEM}) ;{ }^{\star} \mathrm{p}<0.03 v$ saline/control.

were delivered continuously at $1.5 \mathrm{ml} / \mathrm{h}$ by syringe infusion pump (Harvard Apparatus, South Natick, MA). The selection of SCFA concentrations and rate of infusion was based upon the physiological concentrations of each SCFA in the rat colon and previous experience with the specified rate. ${ }^{1-3} 8-12$

All animals were permitted access to water and a fibre free diet containing 5\% w/w kaolin beginning 24 hours postoperatively. After seven days of infusion and an overnight fast, animals were killed with sodium pentobarbital $(50 \mathrm{mg} / \mathrm{kg}$ intraperitoneally) and rapid cardiac exsanguination. Animals who received gastrin receptor blocker were killed 12 hours later than control rats because of an unavoidable laboratory emergency. Plasma gastrin concentration was determined by radioimmunoassay using corresponding human peptides as standards. $^{2122}$ Jejunal samples were harvested for determination of wet weight, histology, and crypt cell proliferation rate by bromodeoxyuridine incorporation (Amersham Proliferation Kit, Arlington Heights, IL). ${ }^{23} 24$ Twenty well oriented crypts and villi per animal were randomly selected and measured for villous height and crypt death. ${ }^{25}$ Jejunal mucosa was harvested from $10 \mathrm{~cm}$ of proximal jejunum and analysed for DNA and protein contents. ${ }^{2627}$ Gastrin was extracted from jejunal tissue samples by boiling in $0 \cdot 1 \mathrm{M}$ acetic acid for 20 minutes. ${ }^{23} 28$ Plasma and tissue gastrin samples were frozen at $-70^{\circ} \mathrm{C}$ and gastrin concentrations were determined by radioimmunoassay (ARUP, Salt Lake City, UT).$^{23} 24$

\section{EXPERIMENT 2}

Nineteen male Sprague-Dawley rats were maintained preoperatively as described in Experiment 1. Rats were anaesthetised with pentobarbital $(50 \mathrm{mg} / \mathrm{kg}$ body weight intraperitoneally) and underwent caecectomy, ileocolonic anastomosis, and placement of an end colonic infusion catheter as described previously.

The animals were assigned to one of two groups (SCFA, saline), and infusions were delivered as described in Experiment 1. After seven days of infusion and an overnight fast, the animals were killed, and a blood sample obtained for plasma enteroglucagon concentration. Jejunal tissue concentrations of enteroglucagon were determined after tissue extraction ${ }^{23} 28$ by radioimmunoassay and subtraction of specifically measured pancreatic glucagon from total $N$-terminal glucagon immunoreactivity. ${ }^{28-31}$ These determinations were performed by Drs Bloom and Ghatei, Hammersmith Hospital, London.
STATISTICAL ANALYSIS

For Experiment 1, randomised two way analysis of variance was performed with the Systat software (Systat, Chicago, IL). If significant treatment effects were found, a protected least significant differences test was performed for multiple comparisons. Complete one way analysis of variance was performed in Experiment 2 using the Systat software.

All data are presented as mean (SEM). Significance values are stated in Figure or Table legends for each end point investigated.

\section{Results}

\section{EXPERIMENT 1}

\section{Body weight}

Control rats who received SCFA gained significantly more weight than control rats who received saline $(12.4(4.2) \mathrm{g} v 2.7(3.7) \mathrm{g}$, $\mathrm{p}<0.01)$. In addition, both groups of rats who received gastrin blocker (saline/gastrin receptor blocker and SCFA/gastrin receptor blocker) gained significantly more weight than saline/control rats $(16.5(2.0)$ and $18.7(2.7) v$ $2 \cdot 7(3 \cdot 7) \mathrm{g}, \mathrm{p}<0 \cdot 01)$.

\section{fejunal weight (Table I)}

Rats who received SCFA/control had significant increases $(p<0.03)$ in jejunal weight when compared with rats who received saline/ control. In the gastrin receptor blocker groups, SCFA did not increase jejunal weight.

\section{Mucosal DNA and protein (Figs 1, 2)}

Both jejunal mucosal DNA and protein content were significantly increased $(p<0.01)$ in control rats who received SCFA compared with saline. In the gastrin receptor blocker groups, SCFA did not change either DNA or protein content.

\section{Crypt cell proliferation (Fig 3)}

SCFA increased crypt cell proliferation in control rats but not in those who received gastrin receptor blocker $(p<0.02)$. In addition, rats who received SCFA/gastrin receptor

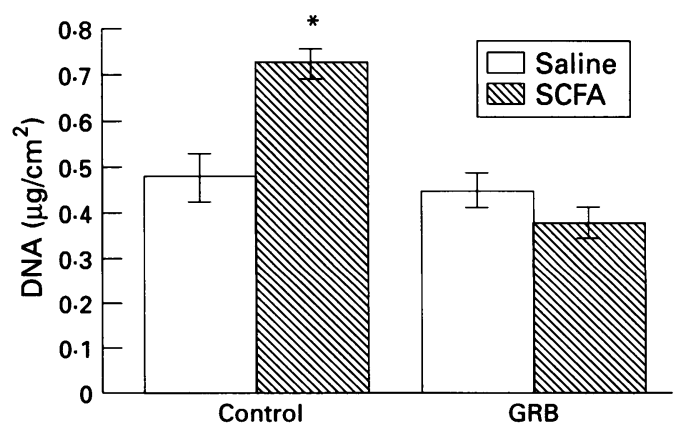

Figure 1: Augmentation of jejunal mucosal DNA content by SCFAs in control (vehicle, $0.9 \% \mathrm{NaCl}$ ) rats when compared with saline. No increase in jejunal DNA content is seen after SCFA administration in rats who received gastrin receptor blocker (GRB). Data are mean (SEM); gastrin receptor blocker $(G R$,
${ }^{\star} p<0.01 \mathrm{v}$ saline/control. 


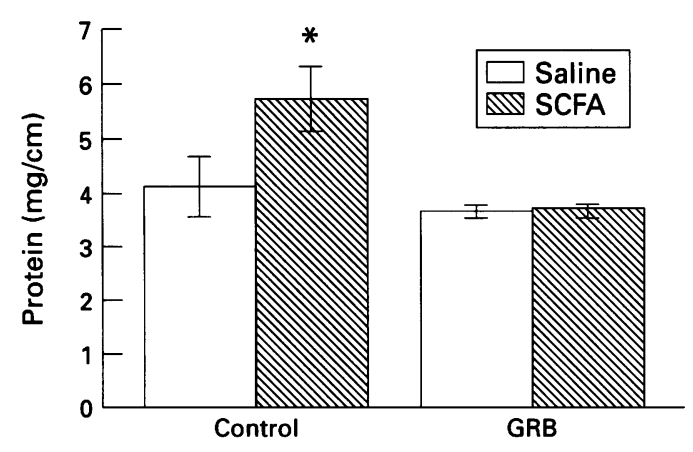

Figure 2: Increase in jejunal mucosal protein content by SCFAs in control (vehicle, $0.9 \% \mathrm{NaCl}$ ) rats when compared with saline. No increase in jejunal protein content is seen after SCFA administration in rats who received gastrin receptor blockers (GRB). Data are mean (SEM); ${ }^{\star} p<0.01 \mathrm{v}$ saline/control.

blocker had a significant increase in crypt cell proliferation when compared with SCFA/ control $(p<0.05)$.

fejunal and plasma gastrin (Fig 4, Table I)

There was a significant increase in jejunal tissue gastrin concentrations in SCFA/control rats $v$ saline/control rats $(\mathrm{p}<0.001)$. No significant differences were seen in gastrin receptor blocker rats who received SCFA or saline (Fig 4). There were no significant differences in plasma gastrin concentrations among groups (Table I).

\section{Histological measurements (Table II)}

There was a significant increase in jejunal villous height in rats who received SCFA/gastrin receptor blocker $v$ saline/gastrin receptor blocker $(p<0.03)$. Significant increases were seen in crypt depth in SCFA rats who received either control or gastrin receptor blocker $(p<0.03)$ when compared with same group saline rats.

\section{EXPERIMENT 2}

Plasma and tissue enteroglucagon concentrations (Table III)

There were no significant differences between groups who received SCFA when compared with those who received saline.

\section{Discussion}

This study corroborated previous findings that colonically infused SCFAs are trophic to rat jejunum $^{8}$ and are associated with increased jejunal gastrin concentrations. ${ }^{10}$ Gastrin receptor blockade abolished most jejunotrophic effects of SCFAs, therefore, local binding of gastrin mediates, in part, SCFA induced jejunotrophism. SCFA administration did not significantly change plasma gastrin concentrations or tissue or plasma enteroglucagon concentrations.

Jejunal growth and proliferation in response to colonically administered SCFA in control groups was shown by increased jejunal weight, mucosal DNA and protein

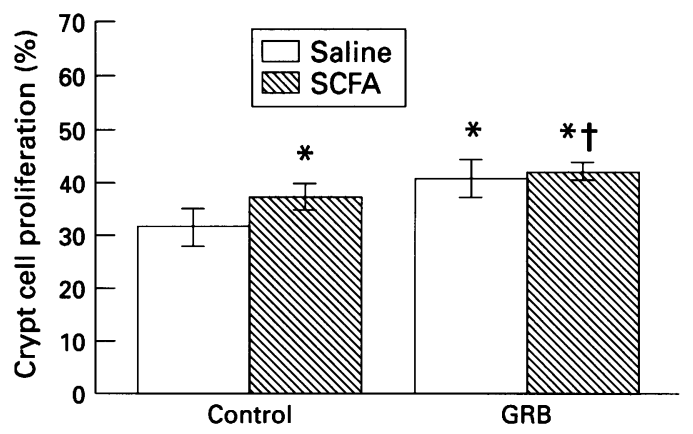

Figure 3: Effects of SCFAs and gastrin receptor blocker (GRB) on jejunal crypt cell proliferation. SCFAs increased crypt cell proliferation in control rats when compared with saline; crypt cell proliferation was also increased in both gastrin receptor blocker groups when compared with saline/control. Additionally, crypt cell proliferation was greater in the SCFA/gastrin receptor blocker group when compared with SCFA/control group. Data are mean (SEM); ${ }^{\star} p<0.02 \mathrm{v}$ saline/control; $\dagger p<0.05 \mathrm{v}$ SCFA/control.

contents, crypt cell proliferation rate, and crypt depth. Villous height was augmented by SCFA administration in the control group, although not to a significant degree $(p=0 \cdot 055)$. SCFA significantly increased concentrations of jejunal gastrin, while not affecting plasma gastrin values. Gastrin receptor blockade with L-365, 260, a selective gastrin/CCK-B receptor antagonist was used to discover if jejunotrophic effects of SCFAs are mediated directly by tissue gastrin. ${ }^{13-20}$ Gastrin receptor blockade abolished SCFA induced increases in jejunal weight, DNA, protein, and crypt cell proliferation, without changing SCFA effects on crypt depth and villous height. Neither SCFAs nor gastrin receptor blocker administration affected plasma gastrin concentrations. We hypothesise that SCFAs may stimulate upregulation of gastrin receptors on jejunal proliferative cells, thereby increasing jejunal gastrin binding without affecting plasma gastrin concentrations. Alternatively, there may be increased $G$ cell gastrin synthesis as well as increased jejunal gastrin binding, with no net change in plasma gastrin concentration. Previous investigations of gastrin action on the small intestine have frequently shown wide variations in plasma gastrin 3233 and small intestinal gastrin concentrations have rarely been measured.

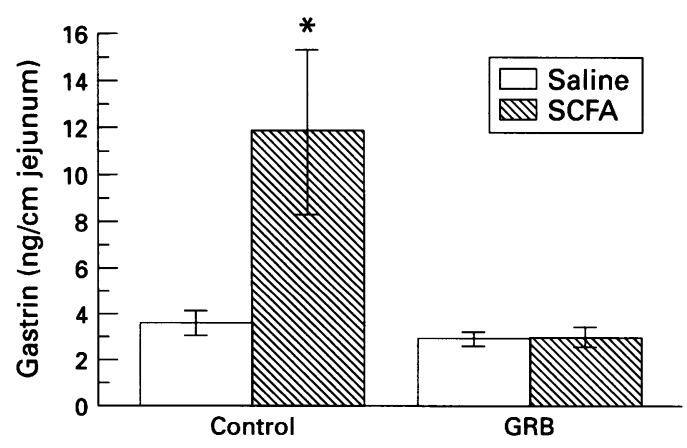

Figure 4: SCFA infusion significantly increased jejunal tissue gastrin content in control (vehicle, $0.9 \% \mathrm{NaCl}$ ) rats when compared with saline. No effect of SCFAs on gastrin content is seen in rats that had received gastrin receptor blocker (GRB). Data are mean (SEM); ${ }^{\star} p<0.001 \mathrm{v}$ saline/control. 
TABLE II Effect of SCFAs and gastrin receptor blocker (GRB) on jejunal histology

\begin{tabular}{lll}
\hline & $\begin{array}{l}\text { Villous height } \\
(\mu \mathrm{m})\end{array}$ & $\begin{array}{l}\text { Crypt depth } \\
(\mu \mathrm{m})\end{array}$ \\
\hline Saline/control & $712 \cdot 4(30 \cdot 2)$ & $217 \cdot 1(5 \cdot 4)$ \\
SCFA/control & $795 \cdot 0(31 \cdot 0)$ & $246 \cdot 9(7 \cdot 0)^{\star}$ \\
Saline/GRB & $784 \cdot 8(28 \cdot 2)$ & $223 \cdot 5(6 \cdot 4)$ \\
SCFA/GRB & $868 \cdot 0(20 \cdot 8) \dagger$ & $241 \cdot 2(4 \cdot 3) \dagger$ \\
\hline
\end{tabular}

Data are mean $(\mathrm{SEM}) ;{ }^{\star} \mathrm{p}<0.03 v$ saline/control; $\mathrm{tp}<0.03 v$ saline/GRB.

The results of this investigation renew interest in the enterotrophic effects of gastrin. Gastrin administration stimulates growth throughout the gastrointestinal tract with the exception of salivary glands, oesophagus, and gastric antrum. ${ }^{34} 35$ Gastrin clearly regulates growth of the acid producing (oxyntic) portion of the stomach ${ }^{34} 36-40$ where it stimulates DNA, RNA, and protein synthesis. ${ }^{35} 3741$ Exogenous gastrin also augments cellular proliferation in duodenal and colonic mucosa ${ }^{39} 41-44$ and increases acinar cell counts, organ weight, and RNA concentrations in the pancreas. 4546

Gastrin mediation of small intestinal growth (beyond the duodenum) is controversial. Gastrin increases weight, DNA synthesis, RNA and protein contents, and expands the crypt cell proliferation zone in rat small intestinal mucosa. ${ }^{34} 414246-50$ In a rat fetal intestine transplant model, exogenously administered gastrin-17 significantly increases intestinal DNA concentration and absorptive capacity. ${ }^{51}$ In vitro, gastrin stimulates DNA synthesis in all intestinal tissue $e^{344347}$ as well as in the intestinal crypt IEC-6 and human cancer LoVo cell lines. ${ }^{5253}$ Several findings, however, argue against a role for gastrin in small intestinal trophism. ${ }^{32} 334554$ Refeeding starved rats results in an increase in crypt cell production rate in the proximal small intestine, but does not correlate with plasma gastrin concentrations (tissue values were not measured). .556 Chronic pentagastrin injection in rats increases duodenal weight but does not change structure

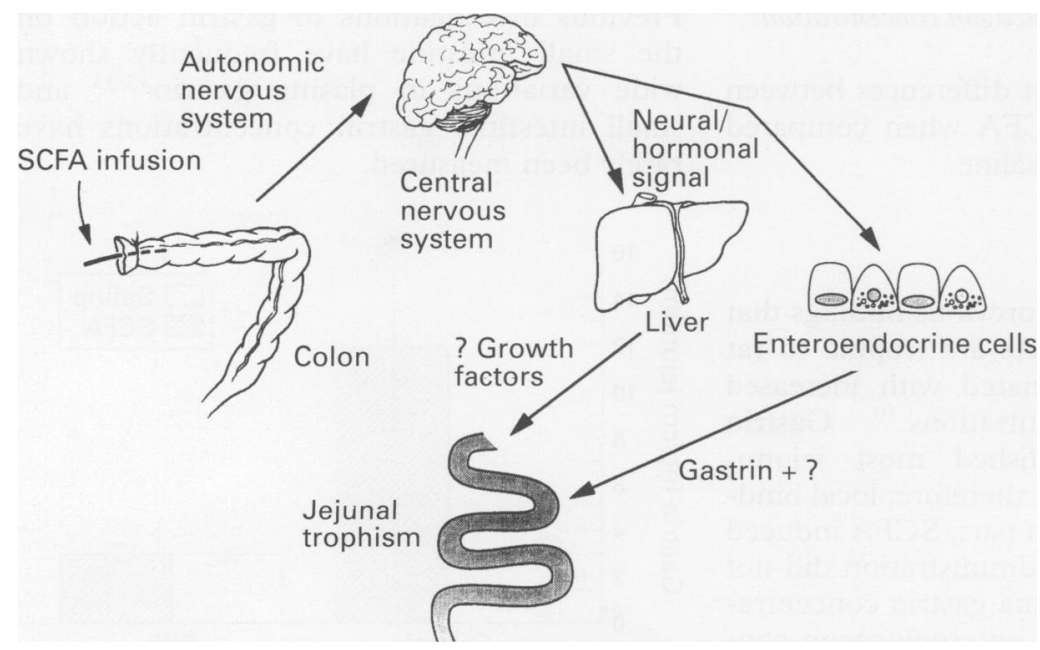

Figure 5: Hypothesis of mechanism of colonic SCFA action on rat jejunum. An autonomic nervous signal, generated in response to colonic SCFA infusion, travels to the central nervous system and generates, in turn, a neural or hormonal signal, which then acts on gastrin producing enteroendocrine cells. The elaborated gastrin then binds to jejunal mucosal receptors, augmenting jejunal growth and proliferation. Hepatic growth factors may additionally participate in this mechanism of trophism (see text). or function of the jejunum. ${ }^{45}$ Additionally, induced endogenous or exogenous hypergastrinaemia in rats has no enterotrophic effects outside the oxyntic stomach. ${ }^{54}$

Evidence of a direct effect of gastrin on small intestinal growth is debatable; however, gastrin probably has a role in the maintenance of intestinal mucosal integrity, as noted by studies relating decreased endogenous gastrin concentrations to intestinal mucosal atrophy. For example, pentagastrin treatment of starved animals prevents decreases in small intestinal protein and RNA content in the rat. In parenterally fed rats, intravenous pentagastrin administration prevents small intestinal weight loss and restores most structural and functional variables to normal. ${ }^{3757}$ Because endogenous production of gastrin is decreased in both starvation and intravenous alimentation, and exogenous gastrin prevents the atrophic changes associated with these conditions, gastrin seems vital for maintaining structural integrity in the small intestine. ${ }^{34} 3657$

Enteroglucagon producing tumours are associated with tremendous proliferation in intestinal mucosa ${ }^{58}$ and enteroglucagon is the peptide hormone most strongly associated with intestinal mucosal growth. 30315960 Fermentable fibre has been shown to stimulate crypt cell production rate in the distal small intestine and colon and plasma enteroglucagon concentrations correlate with the degree of epithelial cell proliferation in these regions. ${ }^{55} 56$ No significant differences were seen in either tissue or plasma enteroglucagon concentrations with colonic SCFA administration in this experiment; therefore, enteroglucagon is not an important mediator of colonic SCFA induced growth of the jejunum.

The mechanism(s) by which colonic infusion of SCFAs promotes jejunal growth clearly involves gastrin. The failure of gastrin receptor blockade to abrogate all effects of SCFAs on jejunal structure (crypt depth, villous height) is consistent with other reports showing varied effects of gastrin on small intestinal growth and function. Alternatively, this may be experimental aberration, which would not be reproducible. Finally, the autonomic nervous system may modulate gastrin's trophic action on the jejunum, possibly by changing local blood flow or receptor expression. Previous investigations in our laboratory show that both divisions of the autonomic nervous system must be intact for colonic SCFA to induce jejunotrophism in the rat. ${ }^{11}$ We postulate that the autonomic nervous system transmits the SCFA induced nervous signal from the colon to the central nervous system, which then elaborates a secondary

TABLE III Effect of SCFAs and gastrin receptor blocker (GRB) on tissue and plasma enteroglucagon

\begin{tabular}{lll}
\hline & \multicolumn{2}{l}{ Enteroglucagon } \\
\cline { 2 - 3 } & Tissue (pmol/g) & Plasma (pmoll) \\
\hline Saline/control & $6.08(0.68)$ & $29 \cdot 0(3.8)$ \\
SCFA/control & $5.72(0.65)$ & $24.3(3.6)$ \\
\hline
\end{tabular}

Data are mean (SEM) 
neural signal, hormone or growth factor that stimulates jejunal growth (Fig 5). This study shows that gastrin, but not enteroglucagon, may be a secondary messenger in transmitting the SCFA induced trophic signal to the jejunum.

The authors gratefully acknowledge the assistance of Dr David Klurfeld and Mr Carlos Llanes. We also thank the staff of Merck Clinical Research for their technical assistance and donation of $L-365,260$.

Part of these data were presented at the 1994 American Gastroenterological Association, New Orleans, LA, USA.

1 Cummings $\mathrm{JH}$. Short chain fatty acids in the human colon Gut 1981; 22: 763-79.

2 McNeil NI, Cummings JH, James WPT. Short chain fatty acid absorption by the human large intestine. Gut 1978; 19: $919-22$

3 Cummings JH, Branch WJ. Fermentation and the production of short chain fatty acids in the human large intestine. In: Vahouny GB, Kritchevsky D, eds. Dietary fiber: basic and clinical aspects. New York: Plenum Press, 1986: 131-52.

4 Roediger WEW. Utilization of nutrients by isolated epithelial cells of the rat colon. Gastroenterology 1982; 83: 424-9.

5 Ardawi MSM, Newsholme EA. Fuel utilization in colonocytes of the rat. Biochem $\mathcal{F} 1985$; 231: 713-9.

6 Desmoulin F, Canioni P, Cozzone PJ. Glutamate-glutamine metabolism in the perfused rat liver: ${ }^{13} \mathrm{C}$ NMR study usin $2-{ }^{13} \mathrm{C}$-enriched acetate. FEBS Lett 1985; 185: 29-32.

7 Sakata T. Stimulatory effect of short chain fatty acids on epithelial cell proliferation in the rat intestine: a possible explanation for the trophic effects of fermentable fibre, gut microbes and luminal trophic effects. Br $₹$ Nutr 1987; 58: 95-103.

8 Kripke SA, Fox AD, Berman JM, Settle RG, Rombeau JL. Stimulation of intestinal mucosal growth with intracolonic infusion of short-chain fatty acids. 7 Parenteral and Enteral Nutrition 1989; 13: 109-16.

9 Frankel WL, Zhang W, Singh A, Klurfeld DM, Don S, Sakata $T$, et al. Stimulation of the autonomic nervous system mediates short-chain fatty acid induced jejunotrophism. Surgical Forum 1992; 43: 24-6.

10 Frankel WL, Zhang W, Singh A, Klurfeld DM, Don S, Sakata $T$, et al. Mediation of the trophic effects of shortchain fatty acids on the rat jejunum and colon. Gastroenterology 1994; 106: 375-80.

11 Reilly KJ, Frankel WL, Bain AM, Llanes C, Klurfeld DM, Rombeau JL. The autonomic nervous system mediates both structural and functional effects of short chain fatty acids in the rat jejunum. Surgical Forum 1993; 44: 20-2.

12 Reilly KJ, Frankel WL, Bain AM, Llanes C, Klurfeld DM Rombeau $\mathrm{JL}$. The autonomic nervous system mediate both structural and functional effects of short chain fatt acids in rat jejunum. Fournal of Parenteral and Enteral Nutrition (in press)

13 Hughes J, Woodruff G, Horwell D, McKnight A, Hill D. Gastrin/cholecystokinin-B receptor pharmacology. In: Walsh JH, ed. Gastrin. New York: Raven Press, 1993: 169-85.

14 Lotti VJ, Chang RSL. A new potent and selective non-peptide gastrin antagonist and brain cholecystokinin receptor 273-80.

15 Nishida A, Yuki H, Tsutsumi R, Miyata K, Kamato T, Ito $\mathrm{H}$, et al. L-365,260, a potent CCK-B/gastrin recepto antagonist, suppresses gastric acid secretion induced by histamine and bethanechol as well as pentagastrin in rats. fpn $\mathcal{F}$ Pharmacol 1992; 58: 137-45.

16 Jensen RT, Huang SC, von Schrenck T, Wank SA, Gardner D. Cholecystokinin receptor antagonists: ability to distinguish various classes of cholecystokinin receptors. In Thompson JC, ed. Gastrointestinal endocrinology: receptors and post-receptor mechanisms. San Diego: Academic Press, 1990: 95-113.

17 Jensen RT, Zhou Z-C, Murphy RB, Jones SW, Setnikar I, Rovati LA, et al. Structural features of various proglumide-related cholecystokinin receptor antagonists. glumide-related cholecystokinin

18 Lignon M-F, Galas M-C, Rodriguez M, Laaur J, Aumelas A, Martinez J. A synthetic peptide derivative that is a A, Martinez J. A synthetic peptide derivative that is a cholecystokinin

19 Huang SC, Zhang L, Chiang H-CV, Wank SA, Maton PN, Gardner JD, et al. Benzodiazepine analogues L-365,260 and $L-364,718$ as gastrin and pancreatic CCK receptor antagonists. Am $\mathcal{F}$ Physiol 1989; 257: G169-74.

20 Murphy MG, Stynik B, Kovacs TOG, Mertz H, Ewanik D, Shingo $S$, et al. The gastrin-receptor antagonist $\mathrm{L}$ 365,260 inhibits stimulated acid secretion in humans. Clin Pharmacol Ther 1993; 54: 533-9.

21 Yalow RS, Berson SA. Radioimmunoassay of gastrin. Gastroenterology 1970; 58: 1-14.

22 Bryant MG, Adrian TE. Gastrin. In: Bloom SR, Long RG, eds. Radioimmunoassay of gut regulatory peptides. Eastbourne: Prager Publishers, 1982: 51-9.

23 Gratzner HG. Monoclonal antibody to 5-bromo- and 5 iododeoxyuridine: a new reagent for detection of DNA replication. Science 1982; 218: 474-5.
24 Morstyn G, Pyke K, Gardner J, Ashcroft R, deFazio A Rhathal P. Immunohistochemical identification of proliferating cells in organ culture using bromodeoxyuridine and a monoclonal antibody. $\mathcal{F}$ Histochem Cytochem 1986 34: 697-701.

25 Lentner C, ed. Geigy scientific tables. Vol 2. West Caldwell, NJ: Ciba-Geigy, 1982: 178.

26 Giles KW, Myers A. An improved diphenylamine method for the estimation of deoxyribonucleic acid. Nature 1965; 206: 93.

27 Bradford MB. A rapid and sensitive method for the quantification of microgram quantities of protein utilizing the principle of protein-dye binding. Ann Biochem 1976; 70: 248 .

28 Nilsson O, Bilchik AJ, Bolerrin JR, Ballantyre GH, Adrian TE, Modlin IM. Distribution and immunocytochemical colocalization of peptide $\mathrm{YY}$ and enteroglucagon in endocrine cells of the rabbit colon. Endocrinology 1991; 129: $139-48$.

29 Thompson JPS, Bloom SR. Plasma enteroglucagon and plasma volume change after gastric surgery. Clin Sci Mol Med 1976; 51: 177-83.

30 Sagor GR, Al-Mukhtar MYT, Ghatei MA, Wright NA, Bloom SR. The effect of altered luminal nutrition on cellular proliferation and plasma concentrations of enteroglucagon and gastrin after small bowel resection in the rat. Br J Surg 1982; 69: 14-8.

31 Sagor GR, Ghatei MA, Al-Mukhtar MYT. Evidence for humoral mechanism after small intestinal resection Exclusion of gastrin but not enteroglucagon Gastroenterology 1983; 84: 902-6.

32 Oscarson J, Hakanson R, Liedberg G, Lundquist G, Sundler F, Thorell J. Variated serum gastrin concentration: trophic effects on the gastrointestinal tract of the rat. Acta Physiol Scand 1979; 475 (suppl): 1-27.

33 Oscarson J, Veen HF, Williamson RCN, Chir B, Ross JS, Malt RA. Compensatory postresectional hyperplasia and starvation atrophy in small bowel: dissociation from endogenous gastrin levels. Gastroenterology 1977; 72: $890-5$

34 Enochs MR, Johnson LR. Hormonal regulation of gastrointestinal tract growth; biochemical and physiologic aspects. In: Glass GBJ, ed. Progress in gastroenterology. Vol III. New York: Grune \& Stratton, 1977: 3-28.

35 Johnson LR. Gastrointestinal hormones. In: Johnson LR ed. Physiology of the gastrointestinal tract. 2nd ed, vol 1 . New York: Raven Press, 1987: 182-95.

36 Johnson LR, Lichtenberger LM, Copeland EM, Dudrick SJ, Castro GA. Action of gastrin on gastrointestinal structure and function. Gastroenterology 1975; 68: $1184-92$.

37 Johnson LR, Enochs MR. Mechanism of pentagastrin stimulation of gastric mucosal growth. Physiologist 1975B; 18: 266.

38 Johnson LR. The trophic action of gastrointestinal hormones Gastroenterology 1976; 70: 278-88.

39 Johnson LR. New aspects of the trophic action of gastrointestinal hormones. Gastroenterology 1977; 72: 788-92.

40 Hakanson R, Blom H, Carlsson E, Larsson H, Ryberg B, Sundler F. Hypergastrinaemia produces trophic effects in stomach but not in pancreas and intestine. Regul Pept 1986; 13: 225-33.

41 Johnson LR, Aures D, Yuen L. Pentagastrin-induced stimulation of protein synthesis in the gastrointestinal tract. Am F Physiol 1969; 217: 251-4

42 Johnson LR, Chandler AM. RNA and DNA of gastric and duodenal mucosa in antrectomized and gastrin-treated rats. Am f Physiol 1973; 224: 937-40.

43 Johnson LR. Gut hormones on growth of gastrointestinal mucosa. In: Chey WY, Brooks FP, eds. Endocrinology of the gut. New Jersey: Charles B Slack, 1974: 163-77.

44 Lichtenberger L, Miller LR, Erwin DN, Johnson LR. Effect of pentagastrin on adult rat duodenal cells in culture. Gastroenterology 1973; 65: 242-51.

45 Mayston PD, Barrowman JA. The influence of chronic administration of pentagastrin on the pancreas of hypophysectomized rats. Gastroenterology 1973; 64: 391-9.

46 Mayston PD, Barrowman JA, Dowling RH. Effect of pentagastrin on small bowel structure and function in the rat. Digestion 1975; 12: 78-84.

47 Enochs MR, Johnson LR. Pentagastrin stimulates tissue growth in stomach and duodenal tissues by stimulating protein and nucleic acid synthesis. Fed Proc 1974; 33: 309.

48 Johnson LR, Guthrie PD. Mucosal DNA synthesis: a short term index of the trophic action of gastrin. Gastroenterology 974; 67: 453-9.

49 Johnson LR, McCormack SA, Wang J. Regulation of gastrointestinal growth. In: Walsh JH, ed. Gastrin. New York: Raven Press, 1993: 285-300.

50 Pansu D, Berard A, Dechelette MA, Lambert R. Influence of secretin and pentagastrin on the circadian rhythm of cell proliferation in the intestinal mucosa in rats. Digestion 1974; 11: 266-74.

51 Leapman SB, Deutsch AA, Grand RJ, Folman J. Transplantation of fetal intestine: Survival and function in a subcutaneous location in adult animals. Ann Surg 1974; 179: $109-14$

52 Conteas CN, Majumdar APN. The effects of gastrin, EGF and somatostatin on DNA synthesis in a small intestinal crypt cell line (IEC-6). Proc Soc Exp Biol Med 1987; 184: crypt cell

53 Kusyk C, McNeil NO, Johnson LR. Stimulation of growth of a colon cancer cell line by gastrin. Am $\mathcal{F}$ Phys $1986 ; 251$ G597-601. 
54 Hakanson R, Sundler F. Trophic effects of gastrin. Scand $\mathcal{f}$ Gastroenterol 1991; 26 (suppl 180): 130-6.

55 Goodlad RA, Lenton W, Ghatei MA, Adrian TE, Bloom SR, Wright NA. Effects of an elemental diet, inert bulk and different types of dietary fibre on the response of the intestinal epithelium to refeeding in the rat and relationship to plasma gastrin, enteroglucagon and PYY concentrations. Gut 1987; 28: 171-80

56 Goodlad RA, Lenton W, Ghatei MA, Adrian TE, Bloom SR, Wright NA. Proliferative effects of 'fibre' on the intestinal epithelium: relationship to gastrin, entero-

57 Johnson LR, Copeland EM, Dudrick SJ, Lichtenberger
LM, Castro GA. Structural and hormonal alterations in the gastrointestinal tract of parenterally fed rats. Gastroenterology 1975; 68: 1177-83.

58 Gleeson MH, Cullen J, Dowling RH. Intestinal structure and function after small bowel by-pass in the rat. Clin $\mathrm{Sci}$ 1972; 43: 731-42.

59 Bloom SR, Polak JM. The hormonal pattern of intestinal adaptation. Scand $\mathcal{F}$ Gastroenterol 1982; 17 (suppl 74): 93-103.

60 Miazza BM, Al-Mukhtar MYT, Salmeron M, Ghatei MA, Felce-Dachez M, Filali A, et al. Hyperenteroglucagonaemia and small intestinal mucosal growth after colonic perfusion of glucose in rats. Gut 1985; 26: 518-24. 